of steam or nebulized saline reduces its viscosity and is always worth a trial when a patient is having difficulty in clearing his bronchi of tenacious sputum.

Exacerbations of bronchitis may be associated with reversible airways obstruction, and if this is suspected a bronchodilator aerosol or a short course of an oral corticosteroid should be prescribed. If a patient with an exacerbation of chronic bronchitis develops central cyanosis and becomes drowsy, it should be assumed that these are manifestations of ventilatory failure, and he should be admitted to hospital without delay. Treatment of this complication is not practicable in the home, since it demands continuous low-concentration oxygen therapy and in some cases artificial pulmonary ventilation.

1 May, J. R., Lancet, 1953, 2, 534

2 Millard, F. J. C., and Batten, J. C., British Medical fournal, 1963, 1, 644. 3 Pines, A., Lancet, 1964, 2, 445.

4 May, J. R., and Delves, D. M., Thorax, 1964, 19, 298.

Pines, A., Raafat, H., Plucinski, K., Greenfield, J. S. B., and Linsell, W. D., British fournal of Diseases of the Chest, 1967, 61, 101.

6 Pines, A., Raafat, H., Plucinski, K., Greenfield, J. S. B., and Solari, M., British Medical fournal, 1968, 2, 735

7 Citron, K. M., et al., Lancet, 1968, 2, 592.

${ }^{8}$ Malone, D. N., Gould, J. C., and Grant, I. W. B., Lancet, 1968, 2, 594.

- Hughes, D. T. D., British Medical Fournal, 1969, 4, 470.

10 Pines, A., Raafat, H., Greenfield, J. S. B., Marshall, M. J., and Solari, M., British Fournal of Diseases of the Chest, 1971, 65, 91 .

${ }^{11}$ British Thoracic and Tuberculosis Association, British fournal of Diseases of the Chest, 1972, 66, 199.

12 British Thoracic and Tuberculosis Association, British fournal of Diseases of the Chest, 1973, 67, 114.

${ }^{13}$ Huddy, R. B., Jones, D. M., and Lee, H. Y., British fournal of Diseases of the Chest, 1973, 67, 241

14 Gent, M., Knowlson, P. A., and Prime, F. J., Lancet, 1969, 2, 1094.

15 Hamilton, W. F. D., Palmer, K. N. V., and Gent, M., British Medical Fournal, 1970, 3, 260 .

16 Langlands, J., Lancet, 1970, 1, 448.

17 British Thoracic and Tuberculosis Association, British fournal of Diseases of the Chest, 1973, 67, 49.

\section{Medicine in the Common Market}

However many problems remain unsolved in other Common Market fields, 1973 seems likely to be remembered as the year in which E.E.C. doctors got together to thrash out their main differences. Last month's open hearing in Brussels ${ }^{1}$ was notably successful in showing that doctors from the Nine really want to remove the barriers to their free movement within the Community. The admirable recent conference at the Royal Society of Medicine (see B.M.F., 17 November, p. 396 , and p. 478 of this week's issue) was concerned more with clinical standards and medical education, but again must have reassured the gloomy who have maintained that standards were too unequal in the E.E.C. for there to be any common ground-despite much evidence already to the contrary from flourishing societies and journals.

Certainly the conference papers showed that each country can provide at least one isolated statistic which its fellows cannot emulate (and might not necessarily want to): the total lack of hospital waiting lists in France; the high proportion of domiciliary confinements with a low perinatal mortality rate in the Netherlands; the direct access of patients to a specialist in West Germany, among others; the long period of specialist training in Britain; and the annual increase of 300 specialist anaesthetists, 200 cardiologists, and 600 paediatricians in Italy. Yet, set against the bulk of standards that most doctors in the E.E.C. accept, these differences assume minor importance: as Professor J. L. Portos said in his initial address,
"I do not think the health of the various populations differs notably from one to the other. We should be surprised by the similarity of methods employed and the results obtained [in treating] . . . five or six medical or surgical emergencies and five or six chronic diseases in the Community."

Given that with certain provisos harmonization should not mean a fall in standards, how can the enormous potential of the E.E.C. be harnessed to improve them ? Disappointingly, the conference failed to include this question on its agenda, and it was left to Professor Ralf Dahrendorf, the E.E.C. Commissioner, to talk in his opening speech of setting up joint research projects. It makes no sense at all for each country in the E.E.C. to try to cover all fields of medical research, and indeed it may be argued that only a joint effort based on the large community population could attract funds and staff on the scale needed for some types of medical research. Experience has shown that at present the public will not contribute directly to European (as opposed to national) research programmes, and so clearly funds will have to come from official sources. The problem could best be tackled by setting up an E.E.C. medical council (modelled perhaps on our Medical Research Council) which could allocate money from a central pool to set up individual research projects and develop existing ones.

There may be an even better case for a similar grant-giving body to allocate funds to existing first-class clinical centres so that they can cope with any extra demands resulting from free access of patients from other countries. Professor J. A. Dudgeon, for instance, estimated that without increased resources free access to the Cardiac Unit at the Hospital for Sick Children in London would double the present average waiting time for British children to two years. Given such funds, several centres in the Nine could be expanded and allowed to make their own particular contribution to the Community. Certainly we should take steps to prevent fear of this type of hazard from slowing the movement towards European medicine, which has finally gathered momentum.

${ }^{1}$ British Medical Journal Supplement, 1973, 4, 39.

\section{Mental or Criminal}

The annual report on the work of the Prison Department is a reminder, if such is needed, of our continuing inefficiency in coping with people who offend against the criminal law. Indeed it might be argued that the doubling of the prison population in the past 30 years or so suggests that our competence in these matters is decreasing.

Clearly the health of the closed, overcrowded community in prison, now standing at over 38,000 according to the report for 1972,1 poses serious problems for the prison medical service, and it is a matter for congratulation that the general health of the inmates remains good and that there have been no major outbreaks of infectious diseases.

The disturbances involving "sit-downs" and the like in our prisons in the summer of last year, symptomatic of unrest among the inmates, are referred to. What has been less publicized is the reaction of the "immature and inadequate" prisoners themselves, who became tense and depressed and required sedation.

A noteworthy feature is the number of cases remanded for psychiatric report-namely, 11,973 as compared with 12,969 